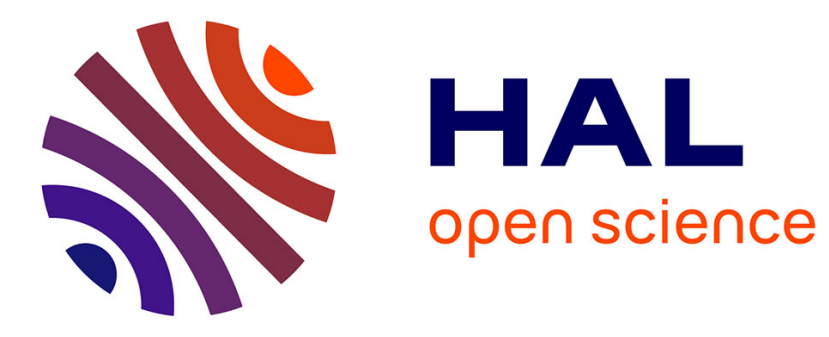

\title{
Some elements about scale effect on scour studies
}

Frédérique Larrarte, Franziska Schmidt, Nisrine Boujia, Vincent Vidal, Arnaud Bontemps, Sidoine de La Roque, Christophe Chevalier

\section{To cite this version:}

Frédérique Larrarte, Franziska Schmidt, Nisrine Boujia, Vincent Vidal, Arnaud Bontemps, et al.. Some elements about scale effect on scour studies. 38th IAHR World Congress, Sep 2019, Panama city, Panama. 7p, 10.3850/38WC092019-0748 . hal-02318439

\section{HAL Id: hal-02318439 \\ https://hal.science/hal-02318439}

Submitted on 18 Oct 2019

HAL is a multi-disciplinary open access archive for the deposit and dissemination of scientific research documents, whether they are published or not. The documents may come from teaching and research institutions in France or abroad, or from public or private research centers.
L'archive ouverte pluridisciplinaire HAL, est destinée au dépôt et à la diffusion de documents scientifiques de niveau recherche, publiés ou non, émanant des établissements d'enseignement et de recherche français ou étrangers, des laboratoires publics ou privés. 


\title{
SOME ELEMENTS ABOUT SCALE EFFECT ON SCOUR STUDIES
}

\author{
FREDERIQUE LARRARTE(1,2), FRANZISKA SCHMIDT ${ }^{(3)}$, NISRINE BOUJIA ${ }^{(3)}$, VINCENT VIDAL ${ }^{(2,4)}$, \\ ARNAUD BONTEMPS ${ }^{(4)}$, SIDOINE DE LA ROQUE ${ }^{(5)}$, CHRISTOPHE CHEVALIER ${ }^{(6)}$ \\ (1) Institut Français des Sciences et Technologies des Transports de l'amenagement et des Reseaux, Bouguenais, France \\ frederique.larrarte@ifsttar.fr \\ (2) Laboratoire d'Hydraulique Saint Venant, Quai Watier, Chatou, France \\ (3) Institut Français des Sciences et Technologies des Transports de l'Aménagement et des Réseaux, Marne la Vallée, France \\ Franziska.schmidt@ifsttar.fr \\ (4) CEREMA, France \\ (5) Cofiroute, France \\ ${ }^{(6)}$ Institut français des sciences et technologies des transports, de l'aménagement et des réseaux, Marne la Vallée, France, \\ christophe.chevalier@ifstar.fr
}

\begin{abstract}
To study the effect of scour on bridge structures, it is necessary to take into account the scale of the problem. To understand the vibrations of a structure, as for example a bridge pier affected by scour phenomenon, several experiments are in complementarity: first the behavior of reduced scale bridge piers can be studied in a hydraulic flume, where all conditions are taken so that the soil is scoured, second, the real-scale dynamical behaviour of bridge piers can be monitored and analyzed. Both approaches are presented here, and the complementary aspect of the results is shown.
\end{abstract}

Keywords: Scour, vibrations, scale effect, laboratory experiments, field study

\section{INTRODUCTION}

The scouring process represents a significant contributing factor in the destabilization and destruction of civil engineering structures (bridges, embankments and buildings) during major flood events, yet our understanding of the involved mechanisms remains highly empirical. For over 30 years, improvements have continuously been introduced relative to monitoring policy and both the preventive and corrective maintenance of rail and road structures. The practical principles of such monitoring programs are organized into different actions: periodic and detailed inspections of structures, risk analyses and diagnostics, enhanced surveillance based on the implementation of in situ instrumentation and/or investigation (including bathymetry surveys). However, despite these efforts, a sensitivity classification of structures to the problem of scouring has not been completely addressed. (Durand et al, 2018) (Takayanagi et al, 2018).

Financed by the French Research Agency (ANR), the SSHEAR project, "Soils, Structures and Hydraulics: Expertise and Applied Research" has been set up to improve scour mechanisms knowledge, to develop innovative experimental and observational tools and hydraulic numerical models at both laboratory and fullscale, and then to build optimized diagnostic, warning and management methods for road infrastructure operators (Chevalier et al, 2018). To overcome this reliance on empiricism, while building general knowledge (especially at the national level) and proposing optimized methods aimed at diagnostics, advanced warning procedures and infrastructure management, SSHEAR sets forth a multi-scale and multi-scientific approach.

The project proposes an intensive research effort on scour erosion based on a multidisciplinary approach that includes the physics of immersed granular media, civil engineering (soil mechanics, free surface hydraulics) and scientific computing, in order to address the practical needs of infrastructure managers (railway and road companies). The experimental and numerical studies undertaken will focus on laboratory-scale models and field cases to produce practical guides and tools for managers and end-users.

This paper reports on both the "laboratory" and "field study" tasks of the SSHEAR project. The first step has been to identify pilot sites, representative of scour vulnerability. After a short description of the scour parameters to be monitored, the instrumentation and experimental set-up will then be presented and, finally, the results will be discussed. 


\section{SOME STATE-OF-THE-ART ELEMENTS}

Scour is a phenomenon that has been studied for years, and quite a lot of empirical formula for scour depth assessment exist. However, (Sheppard et al., 2013) has shown that all of them have limitations, and therefore it remains difficult to anticipate the scour depth affecting a structure. In addition, the evolutions of the flow regime are making it difficult to predict the scour. Therefore, it is becoming imperative to monitor the evolution of scour during the life of the structure. In France, all the bridge structures are usually inspected periodically. However, the presence of a scour hole can be temporarily hidden by very loose soil deposits or a flood can generates quick changes, making these inspections insufficient to assess the actual condition of the work. It is then necessary to develop more efficient techniques for monitoring the structures.

Scouring is the digging action due to eddies generated in a river or marine current encountering a natural (concave bank of meanders) or artificial obstacle (bridge pier, jetty). According to Breusers et al. (1977), equilibrium scour depth $\mathrm{d}$ can be described by equation (1):

$$
d=f\left(\rho, v, g, D, \rho_{s}, d_{o}, U, b\right)
$$

where $\rho$ is the density, $v$ is the kinematic viscosity of the fluid, $g$ is the acceleration of gravity, $D$ is the diameter of the sand and $\rho_{s}$ its density, $d_{0}$ the water depth, $U$ the velocity of the undisturbed flow and $b$ the pier diameter.

Hunt (2009), Fisher et al. (2013), Prendergast and Gavin (2014), Khan and Atamturktur (2015), Wang et al. (2017) have presented reviews of monitoring methods. One of the purposes of the SSHEAR projects is to obtain feedbacks on technics that could be implemented in real situation. Larrarte et al. (2019) present the setup implemented on a site where the velocity profile is measured and the bathymetry evaluated using ultrasonic devices. The need for new technics has also led to the development of methods examining the change in the dynamic response of the structure.

The modal characteristics of a structure, namely the natural frequencies and deformations, are strongly influenced by the interaction between soil, foundation and structure (Foti \& Sabia, 2011). Many authors then examined the feasibility of scour monitoring at bridge supports by vibratory monitoring, following two different approaches. Shinoda and Haya (2008); Samizo et al. (2010); Foti and Sabia (2011); Briaud et al. (2011); Ju (2013); Prendergast et al. (2013); Chen et al. (2014) studied the effect of scour on the response of various bridge components, including piers, foundations and spans. Other authors (Zarafshan et al., 2012; Azhari \& Loh, 2017) have developed scouring sensors. The dynamic response of these sensors, placed near the pile, depends on the scour depth.

Shinoda and Haya (2008) were the first to make a bridge pier vibrate by impact with a well-known, calibrated iron ball, to measure the first natural frequency of the response thanks to an accelerometer placed at the top of the pile. The variation of the measured frequency, compared to the theoretical frequency, allows to detect damage to the foundations of the structure. From vibration tests under ambient excitations, Samizo et al. (2010) have shown that the natural frequency decreases with the scour. The influence of water on the natural frequency has also been also studied. Inspired by the Japanese approach, Briaud et al. (2011) conducted a study on a reduced model in a hydraulic flume: The bridge consisted of a pier and two spans simply supported on the sides of the canal. Two types of piles have been investigated, and therefore two bridge structuress. The accelerometers, unlike the laboratory results, did not allow to follow the evolution of the scour. Therefore this study concluded that the use of accelerometers on site to detect scouring is promising but requires more research.

Prendergast et al. (2013) have developed a numerical model to quantify the scour depth as a function of the measured frequency. This model was validated using experimental laboratory and field test data. In the first, an pile instrumented with an accelerometer at the head was placed in a massive mass of sand. The scour was generated by the progressive removal of a layer of sand from the $50 \mathrm{~mm}$ thick. For each scour depth, the pile was subjected to impact and its recorded transient response. The first natural frequency was subsequently calculated in using a Fast Fourier Transform (FFT). Thus, Prendergast et al. (2013) concludes that given the rigidity of bridge piers, the effect of fluid-structure interaction can be neglected. A study by Lin et al. (2013) also found that the water level variation has little influence on the frequency of a model reduced pile partially buried in the ground. Boujia et al. (2017) has proposed a scour depth sensor (SDS) made of an accelerometer and a rod to measure the scour depth.

\section{LABORATORY EXPERIMENTS}

\subsection{Experimental set up}

The experiments have been carried out at the Laboratoire d'Hydraulique Saint Venant in an open channel which is $16 \mathrm{~m}$ long, $2 \mathrm{~m}$ wide and $0.5 \mathrm{~m}$ high (figure 1). A honeycomb has been placed at the pump outlet to calm the flow. An access ramp allows the passage from the upstream water to the sediment tank ( $0.25 \mathrm{~m}$ deep) that was filled with Hostun sand. We have checked that the velocity profiles, in their non-dimensional form, remain comparable for the flowrate range used in those experiments (figure 2), with $V(z)$ the velocity at a 
distance $z$ from the sand (before any erosion process), $h$ the water level, Vmax the maximum velocity on that profile.

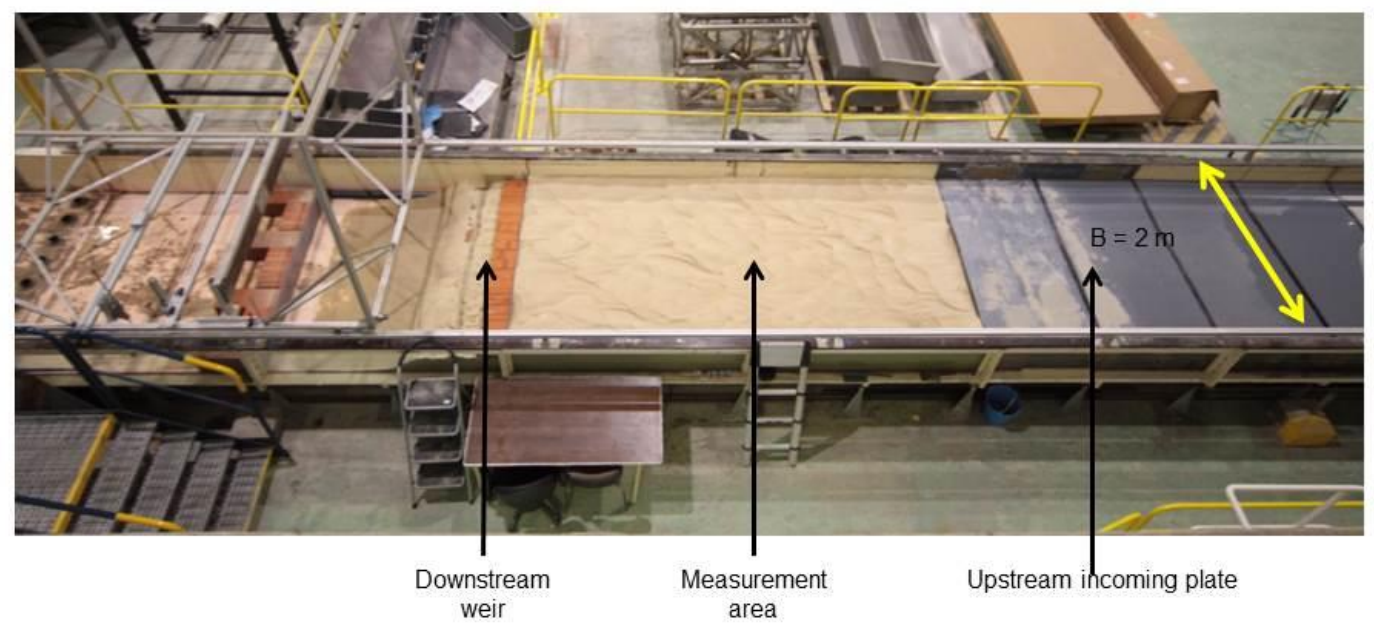

Figure 1. General view of the test facility.

The sand has a D50 equal to $0.6 \mathrm{~mm}$ so, following the Hjulström curve, the sand bed (away from any structure) should not be eroded for the velocity range that has been chosen, below $0.25 \mathrm{~m} / \mathrm{s}$. This situation has been checked, which means that our experiments correspond to clear water scour.

The pile is a cylinder of $0.11 \mathrm{~m}$ diameter and $0.55 \mathrm{~m}$ high. It is implemented in the sand with an initial embedded length of $0.20 \mathrm{~m}$ in order to observe the scour depth increase. In order to determine the frequency, an accelerometer has been implemented on the top of the pile.

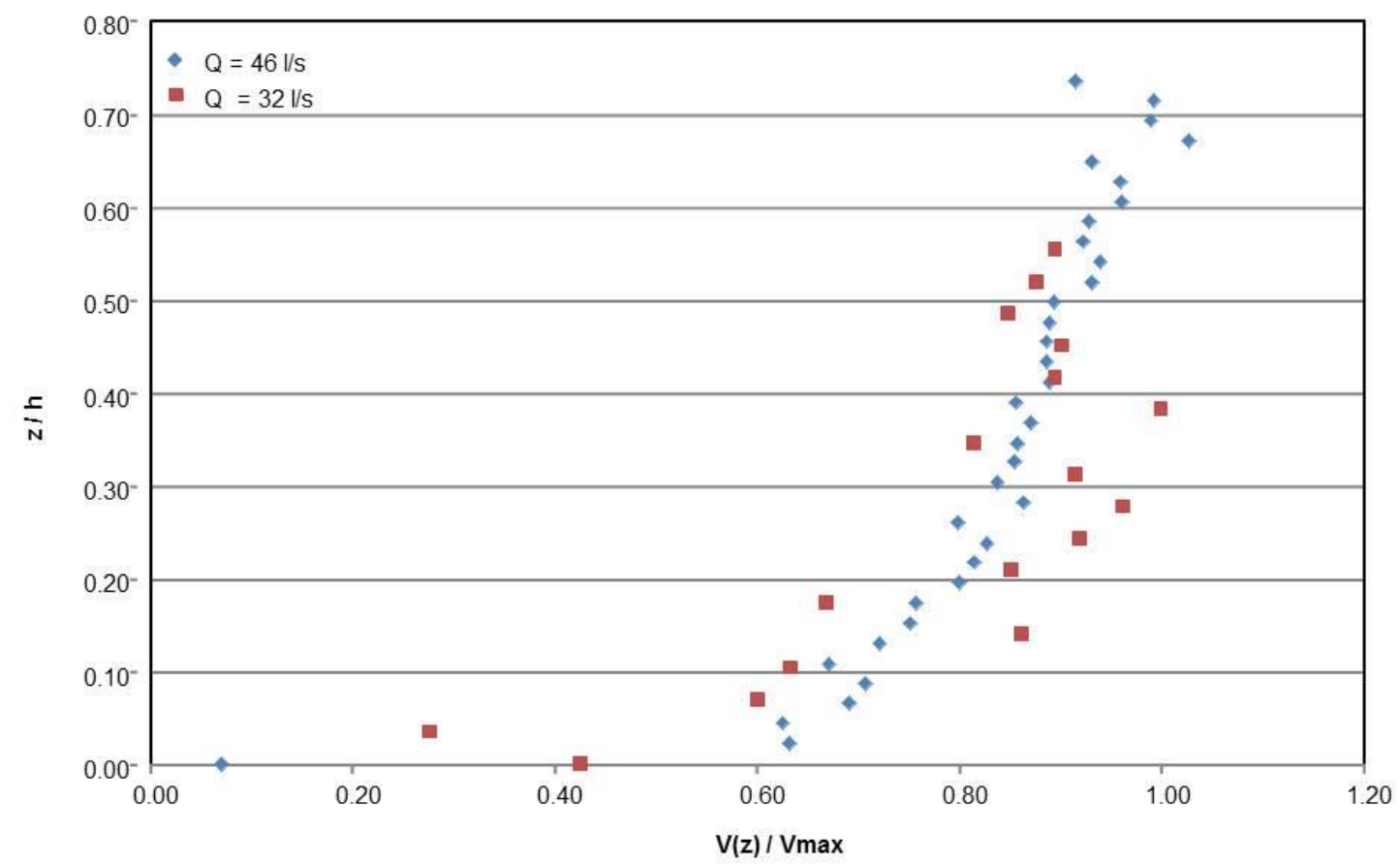

Figure 2. General view of the velocity profiles in the channel.

Procedure for installing the pile is the following. First of all, a hole is created in the sediment tank. Then the pile is embedded of $0.20 \mathrm{~m}$. The soil is then put back in place and compacted gradually by hand. Indeed, given that that the Young's modulus of soil is a key parameter in soil-structure interaction and that it varies greatly with soil density, soil compaction results in high density and thus to ensure the most similar experimental conditions possible between the different tests performed.

The canal is then filled with water until the desired water level h, chosen equal to $0.07 \mathrm{~m}$, is reached. It is important to note that during this phase, a scour of 0.03 to $0.05 \mathrm{~m}$ was observed around the pile. This is mainly due to the low water level at start-up of the filling. Once the water level $\mathrm{h}$ reached, the soil was put back around the pile to fill the gap. However, compaction was not possible. 
Then the flowrate was increased step by step. The duration of each step has been fixed in such a way that the scour depth does not change anymore.

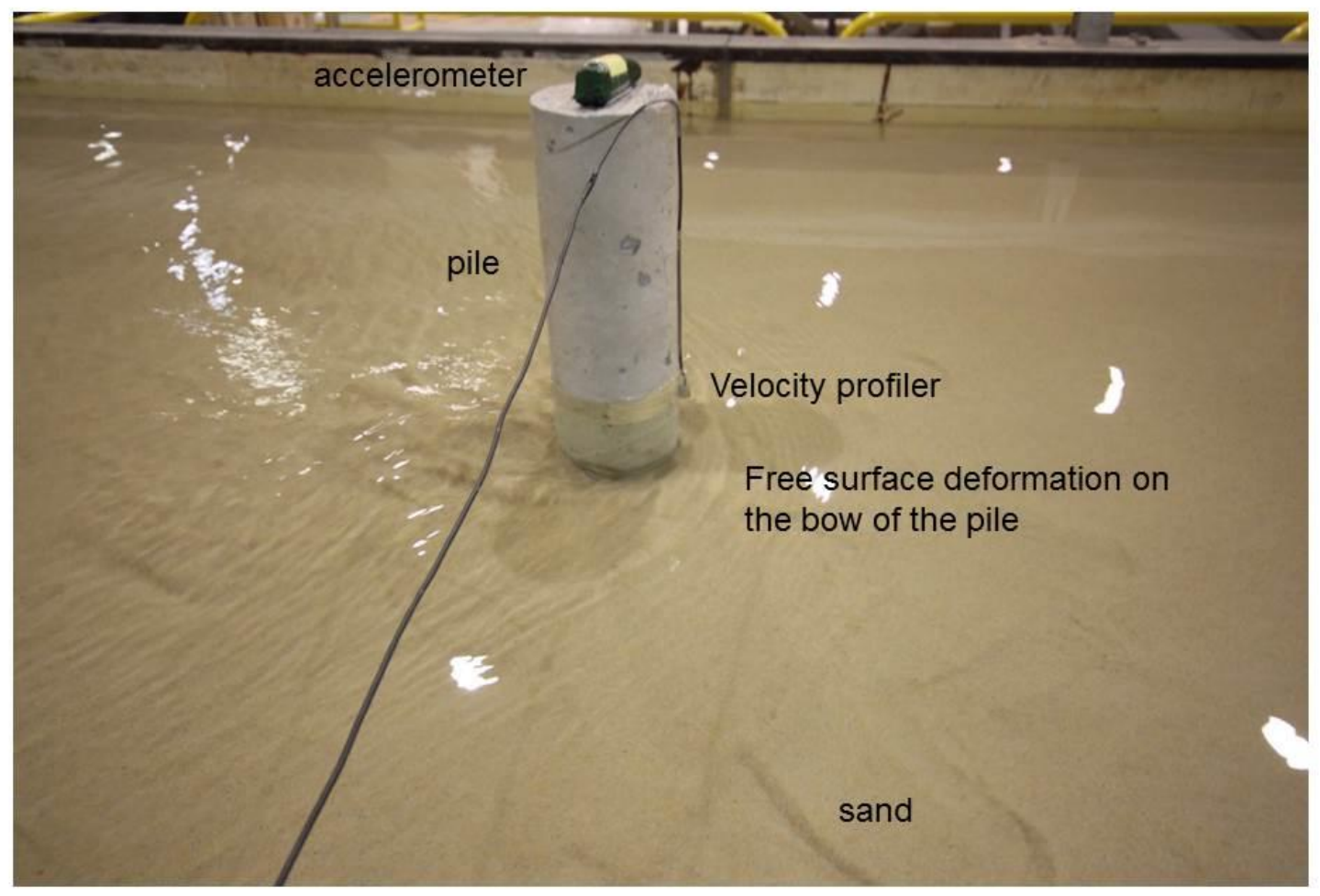

Figure 3. View of the accelerometer at the top of the pile.

\subsection{Preliminary results}

Table 1 summarizes the experimental setups that have been tested. It has been found that it is impossible to erode sediments around the pile significantly at constant flow rate. The maximum flow rate reached is $45 \mathrm{~L} / \mathrm{s}$. If the flowrate grows further, sediment transport becomes very important and the scour depth no longer increases. Maximum "achievable" scour for the pile is $0.12 \mathrm{~m}$ after 80 minutes of testing.

Table 1. Experimental steps.

\begin{tabular}{cccc}
\hline $\begin{array}{c}\text { Flow rate } \\
(\mathrm{L} / \mathrm{s})\end{array}$ & $\begin{array}{c}\text { Water level } \\
\mathrm{m}\end{array}$ & $\begin{array}{c}\text { Duration of the } \\
\text { step } \\
\mathrm{mn}\end{array}$ & $\begin{array}{c}\text { Scour depth } \\
\mathrm{m}\end{array}$ \\
\hline 20 & 0.07 & 15 & 0.04 \\
30 & 0.07 & 15 & 0.06 \\
35 & 0.07 & 15 & 0.09 \\
40 & 0.08 & 15 & 0.10 \\
45 & 0.09 & 20 & 0.12 \\
50 & 0.10 & 20 & 0.12 \\
\hline
\end{tabular}

This variety of scour depths and water levels makes it possible to check the validity of the numerical model and to propose a simplified analytical one: this one involves a unidirectional spring and a helicoidal spring, whose values could be identified (Boujia et al, 2017).

\section{FIELD TESTS}

Monitoring the dynamic behavior of a structure has been tested on a real bridge. This motorway bridge is located over the Loire. It is representative of large structures crossing a river in France in an oceanic climate. This structure is based on 6 piers, 4 of which are located in the riverbed (Figure 4). The two last bathymetric surveys 2011 and 2016 (Bigot et al, 2013, 2016) have shown that complex sediment dynamic processes are 
affecting this structures. Obviously, the comparison between two bathymetric maps is deeply dependent of the date of their realizations, and scour processes are deeply linked to the hydraulic solicitations between this 2 surveys. Then, erosion-accretion cycles could not be observed with simple surveys. Therefore, It has been chosen to implement continuous monitoring devices but there are not operational yet.

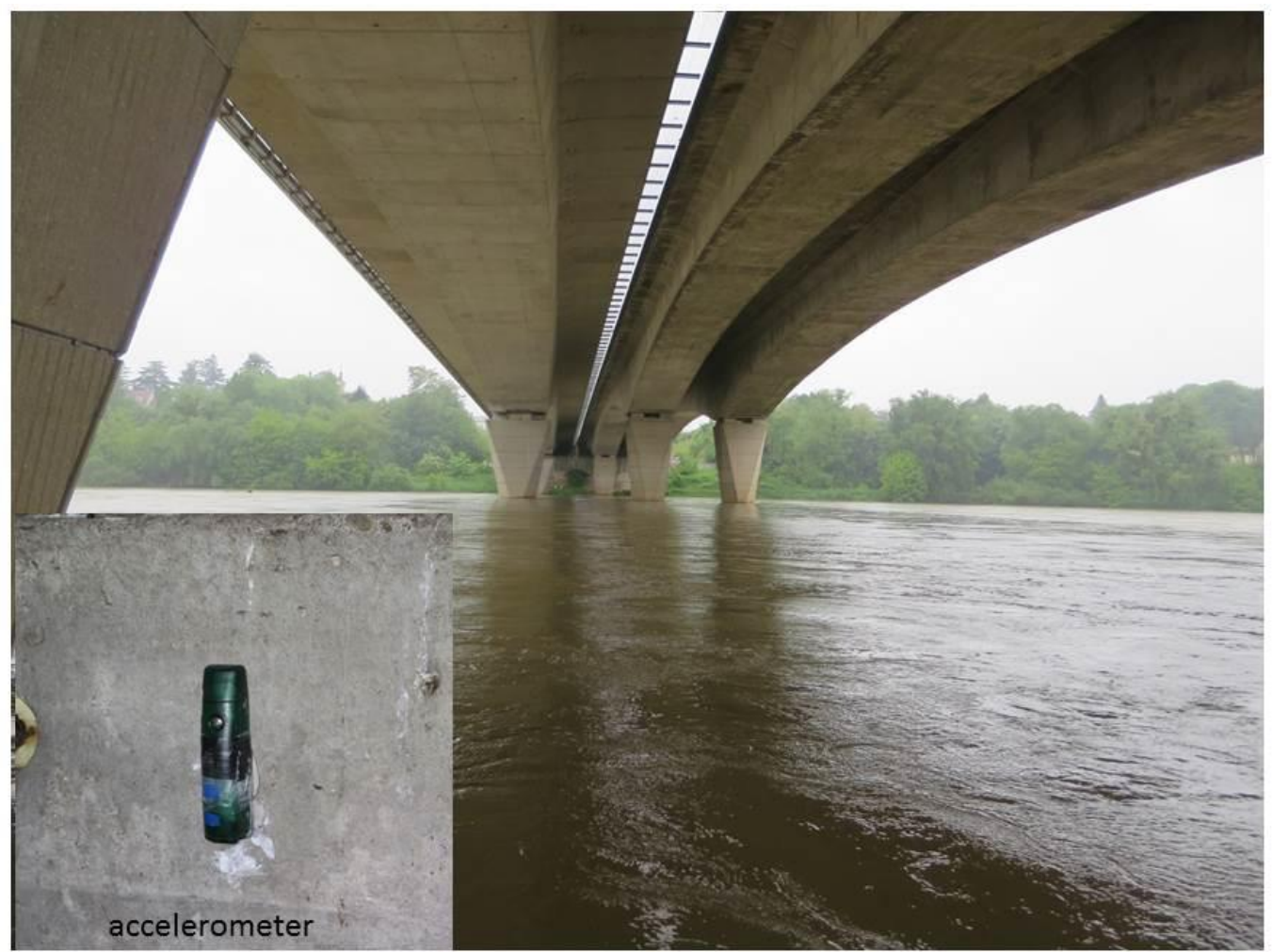

Figure 4. .View of the site in April 2019 and zoom on the accelerometer.

The pile P4, whose scoured state has been proved has been instrumented with accelerometers (Figure 4 and Figure 5): They have been placed at the top of the bridge pier. For this work, some low-cost sensors, autonomous sensors have been used as well as high accuracy, seismic ones. For both these tools, data could be acquired and the first natural frequency has been assessed. Nevertheless, as the monitoring timeframe has been short, no variation in this eigenfrequency could be detected. That is why long-term monitoring is now being installed.

\section{CONCLUSIONS}

This paper has described two approaches to study the effect of scour on bridge piers. On one side, the laboratory scale consists of experimental testing in a hydraulic flume and makes possible to analyze the behavior of the reduced-scale bridge pier in scoured conditions. On the other, the vibrations of a full scale bridge pier have been monitored, the eigenfrequencies have been determined, but their evolution with scour is still be to be proven and this is the scope of ongoing work.

\section{ACKNOWLEDGEMENTS}

The present work benefits from the financial support of the ANR French Research Agency within the project SSHEAR ANR-2014-CE03-0011.

The authors thank the technical staff of IFSTTAR Marne la Vallée (France) for providing the piles as well as Cerema - Laboratoire regional de Blois and Cofiroute staff for the access to the A71 motorway bridge. 


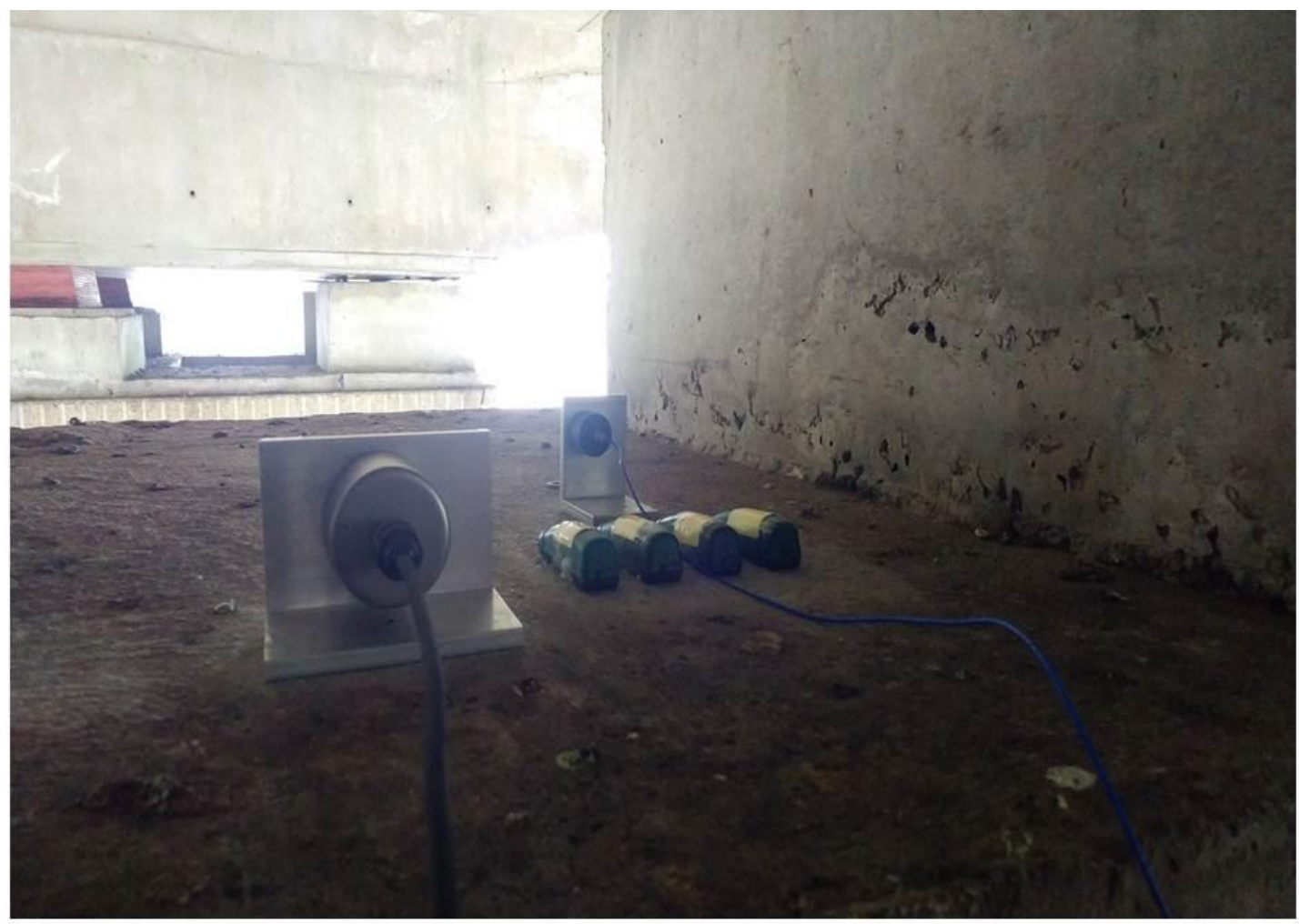

Figure 5. Accelerometers on the real bridge.

\section{REFERENCES}

Bigot D., Piney S., Cofiroute - A71 - PI5/3 et PI1001/05 - River Loire viaduct at Orléans (45) - Bathymetric survey 2011 - Technical Report 121880/B, 2012

Bigot D., Durand E., Cofiroute - A71 - PI5/3 et Pl1001/05 - River Loire viaduct at Orléans (45) - Bathymetric survey 2016 - Technical Report C15RB0001/A, 2016

Boujia N., Schmidt F., Siegert D., Pham Van Bang D., Chevalier C., (2017), Modelling of a bridge pier subjected to scour, Procedia Engineering 199, 2925-2930

Breusers, H. N. C., Nicollet G., Shen H.W. (1977). Local Scour Around Cylindrical Piers. J. Hyd. Res., 15 (3): 211-252

Briaud, J. L., Hurlebaus, S., Chang, K. A., Yao, C., Sharma, H., Yu, O.-Y., Darby, C., Hunt, B. E., \& Price, G. R. (2011). Realtime monitoring of bridge scour using remote monitoring technology. Technical report.

Chevalier, C., Larrarte, F., Schmidt, F., Pham-Van-Bang, D., Durand, E., Gondret, P., de la Roque, S., Cheetham, M. \& Hosseingholian, M. (2018). Research program SSHEAR: recent advances on the understanding and the control of scour phenomena. Ninth International Conference on Scour and Erosion (ICSE), Nov. 5-8, Taipei, Taiwan.

Durand, E., Davi, D. \& Delgado, J.L. (2018). AROSA: A new French guideline for scour at risk-based analysis. Ninth International Conference on Scour and Erosion (ICSE), Nov. 5-8, Taipei, Taiwan, pp 713-720.

Fisher M., Chowdhury M., Khan A., Atamturktur S. (2013). An evaluation of scour measurement devices. Flow Meas. Instrum. 33: 55-67

Hunt, (2009), Monitoring scour critical bridges, A synthesis of highway Practice, NCHRP Synthesis 396, https://trid.trb.org/view/908559

Khan A.A, Huriye S. Atamturktur H.S. (2015); Real time measurement of scour depths around bridge piers and abutments, Final Report, Report No. FHWA-SC-14-05 HEC20

Larrarte F., Chollet H., Battist L., Della Longa Y., Chevalier C. (2019), A French experience of continuous scour monitoring on real sites, 38th IAHR World Congress, September 1-6, 2019, Panama City, Panama

Prendergast, L., Hester, D., Gavin, K., \& O'Sullivan, J. (2013). An investigation of the changes in the natural frequency of a pile affected by scour. Journal of Sound and Vibration, 332(25), 6685-6702.

Prendergast L.J., Gavin K. (2014). A review of bridge scour monitoring techniques. J. Rock Mech. Geotech. Eng. 6(2): 138-149

Samizo, M., Watanabe, S., Sugiyama, T., \& Okada, K. (2010). Evaluation of the structural integrity of bridge pier foundations using microtremors in flood conditions. In Scour and Erosion (pp. 824-833). 
Sheppard, D., Melville, B., \& Demir, H. (2013). Evaluation of existing equations for local scour at bridge piers. Journal of Hydraulic Engineering, 140(1)

Shinoda, M. \& Haya, H.and Murata, S. (2008). Nondestructive evaluation of railway bridge substructures by persussion test. Fourth international conference on scour and erosion, Tokyo, Japan.

Takayanagi, T, Naito, N., Manome, R. \& Nunokawa, O. (2018). Evaluation method using score table for identifying bridge piers vulnerable to scouring in Japan. Ninth International Conference on Scour and Erosion (ICSE), Nov. 5-8, Taipei, Taiwan, pp 721-728.

Wang C., Yu X, Liang F. (2017), A review of bridge scour : mechanism, estimation, monitoring and countermeasures, Nat. Hazards, 87:1881-1906 